\title{
KOMPETENSI GURU DAN MOTIVASI BELAJAR SISWA TERHADAP HASIL BELAJAR MELALUI KEBIASAAN BELAJAR SISWA
}

\author{
Sri Hardianti Sartika, Dadang Dahlan \& Ikaputera Waspada \\ srihardiantisartika@gmail.com; \\ dadangdahlan@upi.edu; \\ ikaputerawaspada@upi.edu
}

\begin{abstract}
ABSTRAK
Penelitian ini dilatarbelakangi oleh terjadinya penurunan hasil belajar siswa SMA. Tujuan penelitian ini untuk mengetahui besarnya pengaruh kompetensi guru dan motivasi belajar terhadap hasil belajar siswa melalui kebiasaan belajar yang dimiliki oleh siswa. Subjek dalam penelitian ini adalah siswa SMA Negeri di Kabupaten Sumedang dengan unit analisis siswa kelas XI IPS. Metode penelitian yang digunakan adalah survey explanatory, dengan teknik pengumpulan data berupa angket yang disebarkan kepada responden penelitian kemudian dilakukan analisis baik secara deskriptif maupun statistik. Analisis data secara statistik melalui pengujian path analisis yang dibantu software SPSS 24. Hasil penelitian menunjukan bahwa : 1) kompetensi yang dimiliki oleh guru tergolong tinggi, 2) motivasi belajar berada pada kategori tinggi kategori tinggi, 3) kebiasaan belajar siswa berada pada kategori tinggi, 4) Hasil belajar berada pada kategori tinggi, 5) Kompetensi guru berpengaruh positif terhadap kebiasaan belajar siswa, 6) Motivasi belajar siswa berpengaruh positif terhadap kebiasaan belajar 7) Kompetensi guru berpengaruh positif terhadap hasil belajar, 8) Motivasi belajar siswa berpengaruh positif terhadap hasil belajar, serta 9) Kebiasaan belajar siswa berpengaruh positif terhadap hasil belajar.
\end{abstract}

Kata Kunci : Kompetensi Guru, Motivasi Belajar, Kebiasaan Belajar, Hasil Belajar

\section{PENDAHULUAN}

Hasil belajar siswa mencerminkan kemampuan dan perkembangan sekaligus tingkat keberhasilan pendidikan, berdasarkan survey dari Trends in International Mathematics and Science Study (TIMSS) pada tahun 2011 menunjukan bahwa Indonesia berada pada urutan ke-45 dari 48 negara, sedangkan pada tahun 2015 berada pada ranking 36 dari 49 negara dalam hal melakukan prosedur ilmiah. Siswa mengalami kesulitan jika dituntut melakukan interprestasi dari berbagai sumber informasi, akibatnya siswa tidak dapat membuat kesimpulan tentang apa yang dia pelajari namun kemampuan siswa dapat dioptimalkan dengan kegiatan rutin, kebiasaan atau dengan konteks sehari-hari (Rahmawati, 2016). Lebih lanjut Global School Ranking oleh The Learning Curve Pearson menunjukan pada tahun 2014 posisi pendidikan Indonesia menempati peringkat terakhir dalam mutu pendidikan di dunia, kemudian pada 2015 berada pada 10 negara dengan mutu pendidikan yang rendah. Meskipun menurut beberapa lembaga pemeringkatan pendidikan yang lainnya dikatakan bahwa mutu pendidikan di Indonesia mengalami peningkatan walau secara tidak signifikan. Hasil pemeringkatan tersebut menunjukan adanya masalah besar yang dihadapi oleh dunia pendidikan di Indonesia yaitu mutu, biaya dan kualitas.

Rendahnya standar pendidikan yang ada telah menjadi fokus utama dalam beberapa dekade terakhir sehingga membutuhkan penanganan serius baik secara empiris maupun teoritis, permasalahan yang ada erat kaitannya dengan hasil belajar pada tingkatan siswa (Stevenson, 2005; Koetzner, 2006). Hasil belajar merupakan kemampuan yang dimiliki siswa melalui proses pembelajaran dan dapat diamati yang terdiri dari pengetahuan, keterampilan intelektual, keterampilan motorik dan sikap (Gagne dan Driscoll, 1988, hlm.36 ; Briggs, 1979, hlm.52). Output 
dari proses belajar didapatkan disekolah yaitu semakin tinggi hasil belajar maka diindikasikan bahwa kegiatan belajar mengajar telah berjalan dengan efektif. Data dari Kementrian Pendidikan dan Budaya (Kemendikbud) menunjukan bahwa nilai rata-rata Ujian Nasional UN tingkat SMA Negeri di Kabupaten Sumedang khususnya mata pelajaran ekonomi mengalami penurunan dari 7,16 pada tahun 2012 menjadi 6,26 pada tahun 2016, terlebih lagi pada tahun 2015 berada pada 4,07. Penurunan pada nilai UN tersebut menggambarkan bahwa hasil belajar siswa belum mencapai target seperti tahun sebelumnya. Hasil belajar siswa seharusnya bersifat stabil meskipun kode pada tes UN dibedakan, karena tingkat kesulitan soal hampir sama setiap tahunnya.

Kegagalan siswa tidak hanya disebabkan rendahnya kemampuan akademis melainkan dipengaruhi juga oleh kebiasaan belajar siswa (Menzel dikutip Rana dan Kausar, 2011 hlm.26). Siswa yang memiliki nilai bagus identik dengan prestasi akademik yang baik sering diasumsikan memiliki nilai prediktif yang dapat digunakan untuk menghalangi gerbang atau membuka antara sekolah dasar dan sekolah menengah pertama, dan juga antara universitas dan profesi sosial tertentu (Sharma, 2005, hlm.69). Pandangan tradisional berpendapat bahwa perbedaan hasil belajar timbul akibat keanekaragaman kecerdasan dan kemampuan kognitif siswa, namun pada kenyataannya disebabkan oleh faktor lain seperti kemampuan belajar, motivasi belajar, kebiasaan belajar, sikap dalam belajar, dan perilaku belajar siswa (YÕlmaz \& Orhan, 2010; Awang, dan Sinnadurai, 2011; Hassanbeigi et.al., 2011 ; Fazal, et.al., 2012; Nonis \& Hudson, 2008; Crede \& Kuncel, 2008; Nouhi dkk., 2008; Nuthana \& Yenagi, 2009; Sarwar dkk., 2010). Penelitian ini hanya akan membahas prediktor hasil belajar dari aspek non-kognif siswa yaitu motivasi belajar dan kebiasaan belajar, serta prediktor ekternal berupa kompetensi guru.

Faktor-faktor non kognitif seperti kebiasaan belajar, keterampilan dan motivasi belajar, serta konstruk sikap menyumbang varians lebih banyak dalam hasil belajar di luar tes standar dan nilai sebelumnya. Kebiasaan belajar merupakan pola tingkah laku yang diadopsi oleh siswa dalam mengejar studinya dan berfungsi sebagai kendaraan dalam proses pembelajaran. Hal ini dijabarkan sejauh mana siswa terlibat dalam tindakan belajar yang rutin, ditandai dengan rutinitas belajar yang sesuai (ulasan misalnya bahan, sesi frekuensi belajar, dll) yang terjadi dalam suatu lingkungan yang kondusif untuk belajar. Pentingnya kebiasaan belajar dan sikap siswa dalam kinerja akademis mereka (Crede dan Kuncel, 2008, hlm.427). Kebiasaan belajar dan sikap yang baik berperan dalam suatu keberhasilan belajar (Nagaraju, 2004, hlm.25). Guru merupakan salah satu faktor dominan yang menjadi input dalam proses transformasi pendidikan disekolah (Hoy dan Miskel, 2001, hlm.19). Faktor guru memiliki konstribusi yang cukup besar yaitu $34 \%$ dalam pendidikan dibandingkan pengelola, sarana fisik, dan waktu belajar (Fatah, 2004, hlm.23).

Ada begitu banyak faktor yang mempengaruhi siswa untuk menumbuhkan kebiasaan belajar yang efektif dan efisien diantaranya keadaan kesehatan, motivasi, kecemasan, lingkungan, infrastruktur yang mendukung seperti buku teks dan kelengkapan koleksi perpustakaan. Motivasi belajar merupakan salah satu faktor penting yang dapat mempengaruhi dan menentukan hasil belajar siswa di sekolah. Motivasi muncul karena adanya dorongan atau keinginan dari diri sendiri untuk melakukan kegiatan belajar di sekolah. Motivasi belajar bertindak sebagai pendorong semangat dalam mengikuti proses belajar di sekolah, siswa yang memiliki dorongan atau keinginan yang kuat dalam dirinya akan memiliki semangat untuk belajar di kelas.

Konsep pengajaran dan kebiasaan dalam pendidikan telah berkembang melewati dua dekade terakhir, penelitian pendidikan juga telah membuktikan bahwa semua siswa adalah individu yang unik bergabung dalam kelas umum yang berasal dari latar belakang sosial-ekonomi dan budaya beragam, memiliki kebiasaan belajar yang berbeda. Bila dikaji lebih dalam mengenai hambatan dalam meningkatkan kualitas pendidikan dilihat dari proses pembelajaran disekolah sangatlah sulit dirinci, karena hambatan yang ada saling berkaitan. Selain itu karakter siswa yang bervariasi dalam hal menerima materi, sehingga kebiasaan belajar yang dimilikinya akan menjadi faktor pendorong atas minat yang muncul dari siswa untuk menerima materi seutuhnya sehingga keefektivitasan hasil belajar akan tercapai.

Manajerial, Vol. 3 No.4 Januari 2018, Hal - 40

http://ejournal.upi.edu/index.php/manajerial/ 


\section{KAJIAN PUSTAKA}

Penelitian ini berdasar pada social learning theory yang merupakan perluasan dari teori belajar behaviouristik. Teori ini dikembangkan oleh Albert Bandura yang menjelaskan bahwa individu dapat berfikir dan mengatur tingkah lakunya, sehingga aspek kepribadian individu melibatkan interaksi dengan lingkungan.

Teori belajar sosial dari Bandura menekankan pada kontrol individu melalui kekuatan pikiran yang aktif dalam membangun realitas secara selektif, mengkodekan informasi, bertindak berdasarkan nilai dan harapan, serta memaksakan struktur dari tindakannya sendiri. Proses dalam mebangun realitas dari pikiran individu memungkinkan perilaku individu untuk dipahami, diprediksi dan berubah. Hasil belajar merupakan produk interaksi kepribadian individu dan lingkungan yang berdasar pada harapan akan hasil tindakannya (Siahi dan Maiyo, 2015, hlm.136)

Hasil belajar siswa dapat dilihat dari peringkat aktualisasi dalam kegiatan belajar siswa yang

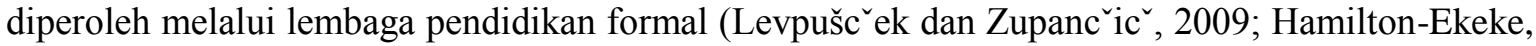
2013). Hasil belajar diaktegorikan menjadi lima yaitu keterampilan intelektual, pengetahuan verbal, strategi kognitif, sikap dan keterampilan motorik (Gagne, 1984, hlm.379). Hasil belajar menunjukkan keberhasilan siswa dalam proses pembelajaran dan dapat diketahui melalui hasil tes seperti nilai harian, nilai tugas, nilai ulangan harian, nilai ulangan tengah semester, nilai ulangan akhir semester, dan nilai ujian nasional (Woodwort dan Marquis, 1957, hlm.76 ; Briggs, 1979, hlm.147; Shuell dan Farber, 2001, hlm.255).

Hasil dari tes yang diberikan kepada siswa mengungkapkan mengenai tingkat pemahaman pembelajaran, namun skor tersebut tidak memberikan penjelasan tentang kesuksesan atau kegagalan yang terjadi. Keberhasilan dalam belajar membutuhkan kontrol individu untuk menciptakan konsistensi rutinitas belajar dalam memperoleh dan membimbing proses kognitif yang dipengaruhi oleh kepribadian individu dan lingkungannya. Kebiasaan belajar yang baik adalah aset yang dimiliki siswa karena akan membantu pencapaian dalam penguasaan di bidang spesialisasi sehingga menghasilkan kinerja yang baik dalam belajar.

Kegagalan siswa tidak hanya disebabkan rendahnya kemampuan akademis melainkan dipengaruhi juga oleh kebiasaan belajar siswa. Siswa yang mengalami kesulitan di sekolah sering tidak memiliki kebiasaan belajar yang memadai dan akan mempengaruhi hasil belajar mereka (Menzel dikutip Rana dan Kausar, 2011 hlm.26). Kebiasaan belajar mewakili konsep siswa tentang cara mencapai tujuan pembelajaran dan tindakan spesifik yang dilakukan Jones, dkk. (1996, hlm.77). Belajar membutuhkan tujuan dan apa yang dipelajari atau biasa disebut sebagai hasil belajar yang sangat tergantung pada sejauh mana individu berhasil mencapai tujuan tersebut (Crow dan Crow, 2007, hlm.261). Pada analisis yang berjudul Study Orientation of High and Low Academic Achievers at Secondary School Level on Pakistan mengungkapkan bahwa siswa dengan kebiasaan dan sikap belajar yang baik cenderung memiliki hasil belajar yang tinggi (Sarwar dkk., 2009, hlm.207). Penelitian lainnya juga menegaskan bahwa kebiasaan belajar yang buruk merupakan salah satu penyebab utama rendahnya hasil belajar siswa (Aisha, dkk., 2002 ; Fielden, 2004 ; Sirohi, 2004 ; Laxminarayan, 2006 ; Mark dan Howard, 2009).

Adanya hubungan yang positif dan signifikan antara hasil belajar siswa dengan faktor-faktor kebiasaan belajar seperti jadwal studi, kebiasaan mencatat dan menulis (Raiz dkk., 2002, hlm.36). Kebiasaan belajar adalah faktor eksternal utama yang memfasilitasi proses pembelajaran seperti rutinitas studi yang mencakup seberapa sering seorang siswa terlibat dalam sesi belajar, meninjau materi, mengevaluasi diri, dan belajar di lingkungan yang kondusif (Crede dan Kuncel, 2008, hlm.427). Kebiasaan belajar bukan merupakan bakat alamiah yang berasal dari faktor bawaan, tetapi merupakan perilaku yang dipelajari dengan cara sengaja dan sadar selama beberapa waktu. Karena diulang selama beberapa waktu, berbagai perilaku itu begitu terbiasakan sehingga akhirnya terlaksana secara spontan tanpa memerlukan pikiran sadar sebagai tanggapan otomatis terhadap suatu proses belajar (Gie, 1995, hlm.12).

Hasil belajar dapat ditingkatkan dengan pendekatan cara siswa belajar dan kebiasaan belajarnya (Josemon, 2006, hlm.265). Faktor kebiasaan belajar berpengaruh signifikan terhadap 
hasil belajar siswa, dengan kata lain jika seorang siswa menunjukkan kebiasaan belajar negatif (misalnya tidak memiliki konsentrasi, merasa bosan, lelah dan mengantuk saat proses pembelajaran, menghabiskan sedikit waktu untuk belajar dan tidak memetakan tujuan langsung yang ingin dicapai), ada kemungkinan bahwa siswa kurang memiliki dorongan untuk terlibat secara maksimal dalam pembelajaran yang produktif selama alokasi waktu sekolah (Okpala dan Onocha, 1988 ; Olatoye dan Ogunkola, 2008). Penelitian lain menunjukan adanya hubungan antara pengetahuan metacognition dan keterampilan serta kebiasaan belajar dan sikap siswa berdasarkan skor skor SSHA (Survey Study Habits and Attitude) siswa di tingkat menengah (Ozsoy dkk., 2009, hlm.166).

Kebiasaan belajar mempengaruhi hasil belajar siswa dengan dipengaruhi berbagai faktor yaitu kepribadian, motivasi belajar, minat dan sikap, serta metode pengajaran (Razia, 2015, hlm.1). Penelitian lain menunjukan bahwa ketidak displinan, motivasi belajar yang rendah, sikap guru yang acuh serta konsep diri yang negatif mengakibatkan rendahnya prestasi belajar siswa (Isangedighi, 1999, hlm.118). Disiplin dan motivasi belajar merupakan indikator paling kuat dari kebiasaan belajar seorang siswa (Goldberg, dkk., 2006, hlm.266). Siswa dengan disiplin diri yang baik dan memiliki inisiatif untuk duduk dan mengerjakan pekerjaan rumahnya maka dapat dikatakan memiliki kebiasaan belajar yang baik dibandingkan dengan individu yang tidak memiliki disiplin diri yang baik, selain itu motivasi belajar yang dimiliki oleh siswa merupakan indikator dalam keefektifan individu dengan kebiasaan belajar yang baik.

Motivasi belajar dalam penelitian ini berdasar pada teori motivasi dari Jhon Keller, teori ini megaskan bahwa motivasi belajar 'merujuk pada ukuran besarnya dan pengaruh dari tingkah laku . . . hal ini merujuk pada pilihan-pilihan yang dibuat seseorang sebagaimana pendekatan yang dilakukan atau dihindari akan sebuah pengalaman atau tujuan, dan tingkat usaha seperti apa yang akan ditekuni terhadap hal-hal tersebut' (Keller, 2004 , hlm.17). Teori motivasi belajar Keller menggunakan dua konsep yaitu pilihan dan usaha untuk menggambarkan alasan yang dibuat atau dihindari seseorang dalam sebuah tugas dan merancang intruksi agar sebuah tugas menjadi lebih menarik. Motivasi belajar membedakan antara usaha, performa, dan konsekuensi. Model dari teori ini sering disebut ARCS Model, yakni attention, relevance, confidence dan satisfaction.

Motivasi belajar muncul dan berkembang karena siswa merasakan adanya suatu kebutuhan (need). Motivasi belajar merupakan daya penggerak yang bersifat psikis, muncul dari dalam diri siswa yang kemudian berkembang membentuk kebiasaan belajar. Motivasi belajar yang tinggi tercermin dari kesungguhan perilaku belajarnya atau dengan kata lain memiliki kebiasaan belajar yang positif dan terbukti dari tingginya hasil belajar siswa (Surachim, 2013, hlm.55).

Motivasi belajar berpengaruh signifikan terhadap hasil belajar fisika melalui kebiasaan belajar yang dimiliki siswa, dengan kata lain jika siswa menguasai keterampilan secara penuh maka akan memperkuat motivasi belajar sehingga akan menghabiskan waktu lebih lama untuk belajar (Nouhi, dkk.,2008, hlm.271). Penelitian lainnya juga menunjukan bahwa kebiasaan belajar merupakan intervening dari motivasi dan hasil belajar siswa, artinya siswa yang memiliki motivasi belajar tinggi diharapkan memiliki hasil beljar yang baik dibandingkan dengan siswa yang kurang memiliki motivasi belajar (Nonis dan Hudson, 2010, hlm.231). Indikator pengukuran motivasi belajar yaitu adanya hasrat dan keinginan berhasil, dorongan dan kebutuhan dalam belajar, adanya harapan dan cita-cita masa depan, adanya penghargaan dalam belajar, adanya kegiatan yang menarik dalam belajar, adanya lingkungan belajar yang kondusif, sehingga memungkinkan siswa dapat belajar dengan (Uno, 2013, hlm.28)

Hubungan antara kebiasaan belajar dan hasil belajar dalam mata pelajaran inti di tingkat sekolah menengah pertama menemukan bahwa peran guru merupakan sub-skala yang paling mempengaruhi kebiassan belajar dibandingkan sub skala lainnya yaitu alokasi waktu berlatih, konsentrasi, catatan, membaca dan mengerjakan tugas (Oluwatimilehin dan Owoyele, 2012, hlm.167). Guru bertugas membantu siswa untuk membentuk kebiasaan dalam kegiatan sehari-hari baik konteks sosial dan pendidikan (Child, 1981, hlm.95). Kompetensi yang dimiliki oleh guru berperan dalam meningkatkan kebiasaan belajar siswa (Perveen, 2011, hlm.35). 
Kompetensi guru dalam pandangan teori Daniel D. Pratt (1989) yang menjelaskan bahwa sifat kompetensi guru berubah saat guru bergerak melalui tahap perkembangan dan lebih jauh lagi bahwa bentuk kompetensi yang menentukan keunggulan dalam pengajaran saling berkaitan. Menurut Pratt (1989, hlm.77) kompetensi guru terbentuk menjadi tiga tahapan sebagai yaitu menguasai keterampilan dan prosedur, pemecahan masalah secara fleksibel dan refleksi kritis terhadap pengetahuan dan nilai. Muzenda (2013, hlm.6) menambahkan bhawa kompetensi guru dalam proses belajar-mengajar adalah konsep multidimensi yang mengukur berbagai aspek yang saling terkait dengan pengetahuan, keterampilan berkomunikasi, penguasaan materi pelajaran, kehadiran di kelas, keterampilan mengajar dan sikap guru.

Standar Kompetensi Guru dikembangkan secara utuh dari 4 kompetensi utama, yaitu: (1) kompetensi pedagogik, (2) kepribadian, (3) sosial, dan (4) profesional. Keempat kompetensi tersebut terintegrasi dalam kinerja guru (PMPNRI, 2007). Pada dasarnya pembelajaran yang efektif dan efisien tidak terlepas dari kemampuan dan keterampilan seorang guru, bagaimana dia dapat mengimplementasikan ilmunya dalam proses interaksi edukatif, kemantapan penggunaan metode mengajar, pengelolaan kelas dan memenej kelas, pengoptimlan situasi dan kondisi berlangsungnya proses belajar mengajar hingga penggunaan media belajar.

Pembelajaran yang efektif dan efisien adalah pembelajaran yang memungkinkan siswa untuk mencapai tujuan pembelajaran yang telah ditetapkan secara maksimal dengan penggunaan komponen pembelajaran (waktu, tenaga, dan biaya) yang minimal. Proses pembelajaran membutuhkan konsistensi dari semua pihak karena output yang dihasilkan dituntut untuk memiliki perubahan sikap dan tingkah laku. Tujuan utama dari kegiatan pembelajaran adalah agar siswa dapat berperan aktif dalam mengembangkan potensi yang ada pada dirinya secara optimal, salah satu indikator dari keberhasilan kegiatan pembelajaran tercermin dari hasil belajar yang ditunjukan dari tinggi rendahnya nilai mata pelajaran yang diperoleh siswa.Berdasarkan penjelasan tersebut maka dapat digambarkan sebagai berikut:

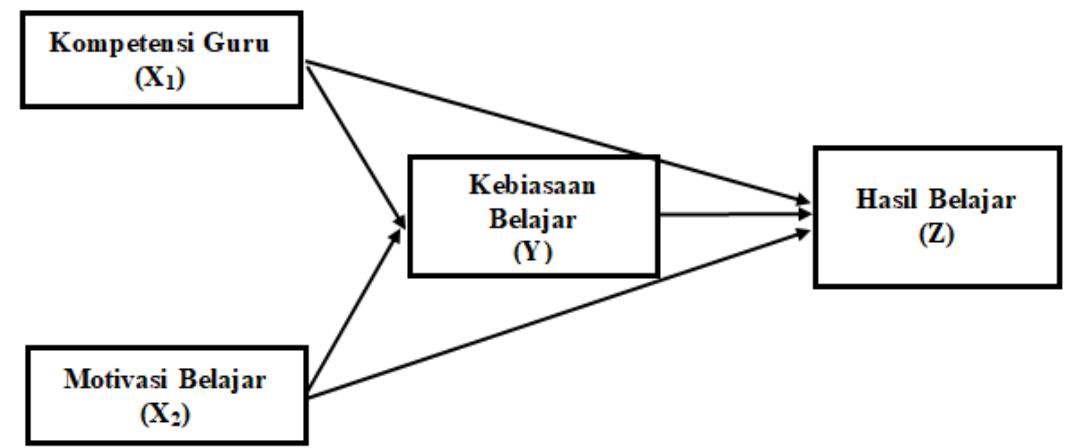

\section{Gambar 1}

\section{Kerangka Berfikir}

\section{METODE PENELITIAN}

Metode yang digunakan dalam penelitian ini adalah survey explanatory yang akan menjelaskan hubungan antar variabel dengan menggunakan pengujian hipotesis. Penelitian dilakukan pada siswa SMA Negeri di Kabupaten Sumedang dengan unit analisis kelas XI IPS. Adapun populasi dalam penelitian ini yaitu 1879 siswa dengan sampel berdasar perhitungan metode slovin yaitu sebanyak 330 siswa. Responden yang ada didominasi oleh perempuan sebesar \% dan laki-laki sebesar \%. Pengujian hipotesis menggunakan path analysis (analisis jalur) dengan bantuan SPSS 24 yang dapat digambarkan sebagai berikut : 


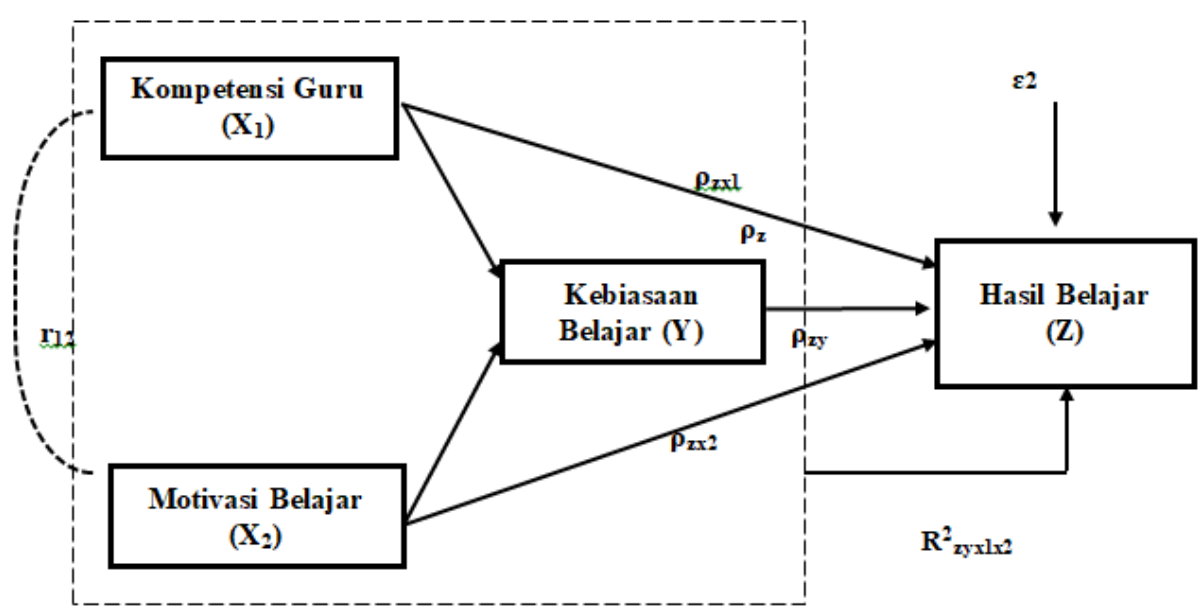

Gambar 2

\section{Analisis Jalur Model Penelitian}

\section{Hipotesis :}

1) Terdapat pengaruh yang positif kompetensi guru terhadap kebiasaan belajar pada siswa

2) Terdapat pengaruh yang positif motivasi belajar terhadap kebiasaan belajar pada siswa

3) Terdapat pengaruh yang positif kompetensi guru terhadap hasil belajar pada siswa

4) Terdapat pengaruh yang positif motivasi belajar terhadap hasil belajar pada siswa

5) Terdapat pengaruh yang positif kebiasaan belajar terhadap hasil belajar pada siswa

\section{HASIL PENELITIAN DAN PEMBAHASAN}

\section{Kompetensi Guru, Motivasi Belajar, Kebiasaan Belajar dan Hasil Belajar}

Hasil analisis deskriptif menunjukan kompetensi guru berada pada kategori tinggi, berdasarkan urutan besarnya tingkat kompetensi dalam indikator kompetensi guru adalah 78,68\% kompetensi kepribadian, 76,54\% kompetensi professional, 70,66\% kompetensi pedagogik, serta 64,45\% kompetensi sosial.

Pandangan siswa mengenai guru yang berkualitas adalah aksesibilitas dan mudah didekati, tidak melakukan diskriminasi, keterbukaan pikiran, penguasaan dan penyampaian materi, antusiasme, humor, serta memiliki pengetahuan yang dapat menginspirasi (Shahmohammad, 2015, hlm.243). Temuan tersebut dapat menyimpulkan bahwa kompetensi guru memiliki peran penting dalam pendidikan karena merupakan kemampuan yang harus dimiliki seorang guru dalam mengembang tugas dan tanggungjawabnya untuk melaksanakan tugas keprofesionalnya yang berhubungan dengan pengelolaan pembelajaran siswa. Kompetensi ini bertujuan untuk mentransfer pengetahuan dan keterampilannya melaui pelaksanakan kewajiban pembelajaran secara professional dan bertanggungjawab.

Variabel kedua dalam penelitian ini adalah motivasi belajar siswa, hasil analisis dekriptif menunjukan bahwa peran motivasi belajar siswa berada pada kategori "tinggi". Motivasi belajar siswa berdasarkan urutan besarnya tingkat motivasi yaitu $86,3 \%$ penghargaan dalam belajar, $73,21 \%$ kegiatan yang menarik dalam pembelajaran, 72,21\% lingkungan belajar yang kondusif, 70,66\% harapan dan cita-cita masa depan, 69,22\% dorongan dan kebutuhan dalam belajar, serta $66,88 \%$. hasrat keinginan untuk berhasil. Berdasarkan temuan yang ada maka dapat disimpulkan bahwa motivasi belajar mempunyai peranan penting dalam memberi rangsangan, semangat, dan rasa senang dalam belajar sehingga yang mempunyai motivasi tinggi mempunyai energi yang banyak untuk belajar Motivasi belajar dianggap sebagai salah satu unsur penting karena bertindak sebagai keseluruhan daya pengggerak baik dari dalam diri maupun dari luar siswa yang 
memberikan arah pada kegiatan belajar sehingga akan mendorong siswa untuk melakukan sesuatu yang diinginkan dengan lebih baik.

Variabel ketiga yaitu kebiasaan belajar siswa dengan hasil analisis deskriptif menunjukan bahwa kebiasaan belajar yang dimiliki siswa berada pada kategori tinggi. Sedangkan urutan berdasarkan tingginya indikator kebiasaan belajar yaitu 68,36\% kebiasaan belajar dalam mengikuti pelajaran, 63,97\% kebiasaan dan kerjainan dalam menulis karya ilmiah, 57,98\% kebiasaan dalam menghadapi ujian, 57,72 \% kebiasaan dalam memantapkan pelajaran, serta 49,28\% kebiasaan dalam membaca buku. Kebiasaan belajar siswa dapat disimpulkan sebagai bentuk perhatian siswa selama pelajaran seperti keaktifan dalam diskusi kelompok atau kebiasaan mencatat apa yang dijelasakan guru namun siswa jarang untuk mengekplore materi pelajaran yang kurang ada atau bahakan kurang dipahami dengan menggunakan menggunakan fasilitas perpustakaan sekolah serta rendahnya minat baca yang dimiliki siswa. Kebiasaan siswa dalam memrpersiapkan materi pelajaran yang akan datang pun jarang terjadi, siswa hanya menunggu guru untuk membahas materi yang ada. Saat mengahadapi ujian atau ulangan, siswa cenderung acuh dengan memilih untuk tidak menjawab semua semua soal atau bahkan bertanya kepada teman pada saat ulangan berlangsung.

Hasil analisis deskrptif mengenai hasil belajar siswa menunjukan hasil belajar yang dimiliki siswa yang bersumber dari rata-rata nilai ulangan siswa selama kelas XI semester ganjil. Hasil belajar yang dimiliki siswa berdasrakan urutan banyaknya jumlah siswa jumlah siswa adalah 206 siswa $(62,42 \%)$ dengan nilai 78-90, 101 siswa $(30,6 \%)$ dengan nilai 66-77, serta 23 siswa $(6,96 \%)$ dengan nilai 78-90.

\section{Kompetensi Guru dan Motivasi Belajar terhadap Kebiasaan Belajar}

Hasil pengujian menunjukan bahwa kompetensi guru dan motivasi belajar siswa secara bersama-sama (simultan) berpengaruh positif terhadap kebiasaan belajar sebesar 18,3\% sedangkan sisanya sebesar $81,7 \%$ merupakan pengaruh variabel lain yang tidak terjelaskan model. Konstribusi kompetensi guru dan motivasi belajar siswa tidak dominan dalam mempengaruhi kebiasaan belajar siswa, hal ini menunjukan bahwa variabel lain yang tidak diteliti dapat memberikan kontribusi yang besar terhadap kebiasaan belajar. Hal ini diperkuat oleh temuan Husain (2000, hlm. 723) dan Razia (2015, hlm.1) bahwa kebiasaan belajar juga dipengaruhi faktor lainnya seperti kepribadian, disiplin, minat dan sikap belajar, metode pengajaran metode belajar dan keterampilan belajar.

Kebiasaan belajar bukan merupakan bakat alamiah yang berasal dari faktor bawaan, tetapi merupakan perilaku yang dipelajari dengan cara sengaja dan sadar selama beberapa waktu krena diulang selama beberapa waktu, berbagai perilaku itu begitu terbiasakan sehingga akhirnya terlaksana secara spontan tanpa memerlukan pikiran sadar sebagai tanggapan otomatis terhadap suatu proses belajar (Gie, 1995, hlm.12). Perhitungan statistik mengenai besarnya pengaruh antar variabel kompetensi guru dan motivasi belajar terhadap kebiasaan belajar tergambar sebagai berikut

\section{Tabel 1}

\section{Ringkasan Hasil Estimasi Parameter Koefisisen Jalur Kebiasaan Belajar}

\begin{tabular}{lllll}
\hline Model & $\begin{array}{l}\text { Koefisien } \\
\text { Jalur }\end{array}$ & t & P & Hasil Uji R $\mathbf{R}^{\mathbf{2}}$ \\
\hline Model Kebiasaan Belajar & & & & \\
Kebiasaan Belajar $\leftarrow$ Kompetensi Guru & 0,162 & 2,915 & $\jmath, 004$ & signifikan 0,183 \\
Kebiasaan Belajar $\leftarrow$ Motivasi Belajar & 0,330 & 5,931 & 0,000 & signifikan \\
\hline
\end{tabular}

Sumber : Hasil Penelitian, data diolah (2017)

Pada tabel 3 dapat dijelaskan bahwa besarnya pengaruh variabel kompetensi guru terhadap kebiasaan belajar siswa adalah 0,162 atau sebesar 2,62 \%. Walaupun pengaruh ini relatif kecil namun signifikan yang ditunjukan oleh perolehan nilai probability yaitu $0,004<0,05\left(\mathrm{P}_{\text {hitung }}<\alpha\right)$ dan uji $\mathrm{t}$ juga menunjukan 2,436 $>1,967$ ( $\left.\mathrm{t}_{\text {hitung }}>\mathrm{t}_{\text {tabel }}\right)$. Hal ini mengindikasikan bahwa variabel kompetensi guru berpengaruh terhadap kebiasaan belajar siswa pada mata pelajaran ekonomi, artinya semakin tinggi kompetensi yang dimiliki oleh guru maka kebiasaan belajar siswa akan 
semakin efektif, begitupun sebaliknya jika kompetensi yang dimiliki oleh guru menurun maka kebiasaan belajar siswa akan menurun. Kondisi ini sejalan dengan Perveen (2011, hlm.35) bahwa kompetensi yang dimiliki oleh guru berperan dalam meningkatkan kebiasaan belajar siswa.

Pembelajaran yang efektif dan efisien tidak terlepas dari kemampuan dan keterampilan seorang guru yaitu bagaimana dia dapat mengimplementasikan ilmunya dalam proses interaksi edukatif, kemantapan penggunaan metode mengajar, pengelolaan kelas dan memenej kelas, pengoptimlaan situasi dan kondisi berlangsungnya proses belajar mengajar hingga penggunaan media belajar. Child $(1981$, hlm.95) menyatakan bahwa 'guru bertugas membantu siswa untuk membentuk kebiasaan dalam kegiatan sehari-hari baik konteks sosial dan pendidikan'.

Tabel 3 juga menjelaskan mengenai besarnya pengaruh motivasi belajar terhadap kebiasaan belajar siswa adalah 0,330 atau sebesar $10,89 \%$. Pengaruhnya memang lebih besar daripada variabel kompetensi guru namun masih relatif kecil, nilai signifikasi dapat ditunjukan oleh perolehan nilai probability yaitu $0,000<0,05\left(\mathrm{P}_{\text {hitung }}<\alpha\right)$ dan uji t yang menunjukan 5,931 $>1,967$ $\left(t_{\text {hitung }}>\mathrm{t}_{\text {tabel }}\right)$. Hal ini mengindikasikan bahwa variabel motivasi belajar berpengaruh terhadap kebiasaan belajar siswa pada mata pelajaran ekonomi, artinya semakin tinggi motivasi belajar yang dimiliki siswa maka kebiasaan belajar siswa akan semakin efektif, begitupun sebaliknya jika motivasi belajar menurun maka kebiasaan belajar siswa akan menurun.

Keadaan ini sejalan dengan penelitian yang dilakukan Goldberg, dkk. (2006, hlm.266) bahwa 'disiplin dan motivasi belajar merupakan indikator paling kuat dari kebiasaan belajar seorang siswa'. Siswa dengan disiplin diri yang baik dan memiliki inisiatif untuk duduk dan mengerjakan pekerjaan rumahnya maka dapat dikatakan memiliki kebiasaan belajar yang baik dibandingkan dengan individu yang tidak memiliki disiplin diri yang baik, selain itu motivasi belajar yang dimiliki oleh siswa merupakan indikator dalam keefektifan individu dengan kebiasaan belajar yang baik. Indikator motivasi belajar yang digunakan dalam penelitian ini berada pada kategori tinggi. Indikator motivasi belajar yang dimaksud yaitu hasrat dan keinginan berhasil, dorongan dan kebutuhan dalam belajar, harapan dan cita-cita masa depan, pengahargaan dalam belajar, kegiatan yang menarik dalam belajar, serta lingkungan belajar yang kondusif.

Setiap individu tentunya menginginkan suatu keberhasilan dalam segala hal, tidak terkecuali seorang siswa yang ingin berhasil dalam hal belajarnya. Keinginan berhasil dalam belajar dapat dilihat dari rasa ingin tahu dan kesungguhan siswa dalam mengerjakan tugas, sehingga timbulnnya dorongan dan kebutuhan untuk belajar dengan kepercayaan diri dalam mengetjakan tugas dan menghindari peniruan tugas pada teman karena adanya ketakutan terhadap kegagalan. Motivasi belajar juga tercermin dengan adanya harapan dan cita-cita siswa pada masa depan yang harus didukung oleh lingkungan belajar yang kondusif.

Motivasi belajar dibutuhkan untuk membentuk kebiasaan belajar yang efektif karena motivasi dalam belajar berperan sebagai semangat dan rasa senang dalam belajar sehingga siswa yang mempunyai motivasi belajar tinggi mempunyai energi yang banyak untuk melaksanakan kegiatan belajar. Siswa yang mempunyai motivasi belajar tinggi akan memiliki sedikit ketetinggalan dan kesalahan yang dilakukan selama proses pembelajaran sehingga memungkinkan siswa untuk mencapai tujuan pembelajaran yang telah ditetapkan secara maksimal dengan penggunaan komponen pembelajaran (waktu, tenaga, dan biaya) yang minimal.

\section{Kompetensi Guru, Motivasi Belajar dan Kebiasaan Belajar terhadap Hasil Belajar}

Hasil pengujian menunjukan bahwa adanya pengaruh variabel kompetensi guru, motivasi belajar dan kebiasaan belajar secara bersama-sama (simultan) terhadap hasil belajar sebesar 14,5\% sedangkan sisanya sebesar $85,5 \%$ merupakan pengaruh variabel lain yang tidak terjelaskan model. Konstribusi kompetensi guru, motivasi belajar, dan kebiasaan belajar siswa tidak dominan mempengaruhi hasil belajar.

Keadaan tersebut sejalan dengan penelitian yang dilakukan Emamepur dan Shams (2007, hlm.210) bahwa hasil belajar tidak hanya timbul akibat keanekaragaman kecerdasan dan kemampuan kognitif siswa namun pada kenyataannya disebabkan oleh faktor lain yaitu faktor nonkognitif siswa. Diperkuat olah teori Gagne bahwa hasil belajar dipengaruhi oleh faktor dalam diri 
siswa dan faktor luar siswa yang keduanya saling berinteraksi (Sagala, 2012, hlm.17). Berdasarkan kajian terdahulu tersebut maka wajar saja jika kontribusi yang relatif kecil karena faktor yang mempengaruhi hasil belajar sangatlah luas namun penelitian ini hanya berfokus pada faktor yang memepengaruhi hasil belajar yaitu faktor internal berupa motivasi belajar siswa dan faktor eksternal berupa kompetensi guru yang tercermin dalam Kegiatan Belajar Mengajar (KBM), dengan intervening kebiasaan belajar siswa sehingga tidak menutup kemungkinan faktor lain itu yang lebih besar mempengaruhi hasil belajar.

Hasil perhitungan statistik didapatkan perhitungan pengaruh variabel kompetensi guru, motivasi belajar dan kebiasaan belajar terhadap hasil belajar, baik pengaruh secara langsung maupun tidak langsung sebagai berikut :

Tabel 2

Ringkasan Hasil Estimasi Parameter Koefisisen Jalur Hasil Belajar

\begin{tabular}{lcccccc}
\hline Model & $\begin{array}{l}\text { Koefisien } \\
\text { Jalur }\end{array}$ & SE & t & P & Hasil Uji & $\mathbf{R}^{\mathbf{2}}$ \\
\hline Model Hasil Belajar & & & & & & \\
Hasil belajar $\leftarrow$ Kebiasaan Belajar & 0,132 & 0,028 & 2,337 & 0,020 & Signifikan & 0,145 \\
Hasil Belajar $\leftarrow$ Kompetensi Guru & 0,141 & 0,037 & 2,436 & 0,015 & Signifikan & \\
Hasil Belajar $\leftarrow$ Motivasi Belajar & 0,216 & 0,044 & 3,608 & 0,000 & Signifikan & \\
\hline Sun
\end{tabular}

Sumber : Hasil Penelitian, data diolah (2017)

Pada gambar 4 dapat menjelaskan mengenai pengaruh kompetensi guru terhadap hasil belajar yaitu 0,141 atau sebesar $1,988 \%$. Pengaruh nya relatif kecil namun signifikan yang ditunjukan dengan perolehan nilai probability yaitu $0,015<0,05\left(\mathrm{P}_{\text {hitung }}<\alpha\right)$ dan uji $\mathrm{t}$ juga menunjukan 2,436 $>1,967\left(\mathrm{t}_{\text {hitung }}>\mathrm{t}_{\text {tabel }}\right)$. Hal ini menunjukan bahwa variabel kompetensi guru berpengaruh terhadap hasil belajar siswa pada mata pelajaran ekonomi, artinya semakin tinggi kompetensi yang dimiliki oleh guru maka hasil belajar siswa akan semakin efektif, begitupun sebaliknya jika kompetensi yang dimiliki oleh guru menurun maka hasil belajar siswa akan menurun.

Kondisi tersebut sejalan dengan hasil penelitian yang dilakukan Heck (2007, hlm.421) bahwa kompetensi guru dengan kategori efektifitas kelas yang menagacu pada fakta dilapangan saat pengajaran berlangsung di kelas serta kareterstik persiapan secara profesional berpengaruh signifikan terhadap hasil belajar siswa. Efektifitas kelas menagacu pada fakta dilapangan yang muncul saat pengajaran berlangsung di kelas, sedangkan karakteristik persiapan profesional dan perizinan mengacu pada gambaran latar belakang guru, persiapan profesional, sertifikasi, keterampilan, dan tugas mengajar.

Penelitian sejenis juga dilakukan oleh Hussey dan Smith (2010, hlm.127) bahwa pengalaman mengajar guru, kurikulum pendidikan, hubungan dan interaksi antara siswa, guru dan materi, motivasi belajar siswa dan motivasi guru dalam mendidik, serta penggunaan model pembelajaran mempengaruhi hasil belajar siswa. Allexander (2013, hlm.6) menambahkan bahwa guru adalah faktor berbasis sekolah yang paling penting dan sebagai penentu utama dalam mempengaruhi hasil belajar. Kompetensi guru berpengaruh terhadap hasil belajar siswa, karena pada dasarnya kompetensi ini merupakan kecakapan yang dimiliki oleh guru agar siswa dapat tertarik pada mata pelajaran yang diajarkan oleh guru sehingga menimbulkan prestasi belajar yang baik. Kompetensi guru sangat penting karena dalam praktiknya, kompetensi guru merupakan input untuk memaksimalkan hasil belajar pada siswa.

Selain berpengaruh langsung terhadap hasil belajar, variabel kompetensi guru juga berpengaruh secara tidak langsung melalui kebiasaan belajar yang dimiliki siswa. Besaran pengaruh tidak langsung ditunjukan oleh koefisien jalur yaitu 0,162 atau 2,622\%. Temuan tersebut sejalan dengan Oluwatimilehin dan Owoyele (2012, hlm.167) meneliti hubungan antara kebiasaan belajar dan hasil belajar dalam mata pelajaran inti di tingkat sekolah menengah pertama menemukan bahwa peran guru merupakan sub-skala yang paling mempengaruhi kebiassan belajar dibandingkan sub skala lainnya yaitu alokasi waktu berlatih, konsentrasi, catatan, membaca dan mengerjakan tugas. 
Selanjutnya pengaruh motivasi belajar terhadap hasil belajar yaitu 0,216 atau sebesar 4,66 \%. Pengaruh yang relatif kecil namun signifikan yang ditunjukan dengan perolehan nilai probability yaitu $0,000<0,05\left(\mathrm{P}_{\text {hitung }}<\alpha\right)$ dan uji t juga menunjukan 3,608 $>1,967$ ( $\mathrm{t}_{\text {hitung }}>\mathrm{t}_{\text {tabel }}$ ). Hal ini menunjukan bahwa variabel motivasi belajar siswa berpengaruh terhadap hasil belajar siswa pada mata pelajaran ekonomi, artinya semakin tinggi motivasi belajar yang dimiliki oleh siswa maka hasil belajar siswa akan semakin efektif, begitupun sebaliknya jika motivasi belajar yang dimiliki oleh siswa menurun maka hasil belajar siswa akan menurun. Temuan ini sejalan dengan pendapat Dalyono (2009, hlm.57) bahwa motivasi untuk belajar dalam diri siswa dapat muncul apabila diawali dari siswa itu sendiri yang mana dapat menentukan baik tidaknya dalam mencapai tujuan, semakin besar motivasinya akan semakin besar kesuksesan dalam belajar. Hal ini dipertegas oleh Sadirman (2011, hlm.75) bahwa hasil belajar akan optimal jika ada motivasi belajar yang tepat.

Selain berpengaruh langsung terhadap hasil belajar, variabel motivasi belajar siswa berpengaruh secara tidak langsung melalui kebiasaan belajar. Besaran pengaruh tidak langsung ditunjukan oleh koefisien jalur yaitu 0,259 atau $6,7 \%$. Temuan tersebut sejalan dengan Nouhi, dkk. (2008, hlm.271) bahwa motivasi belajar berpengaruh signifikan terhadap hasil belajar fisika melalui kebiasaan belajar yang dimiliki siswa.

Penelitian ini juga menjelaskan adanya pengaruh kebiasaan belajar terhadap hasil belajar yaitu 0,132 atau sebesar $1,74 \%$. Pengaruh yangrelatif kecil namun signifikan, hal ini ditunjukan dengan perolehan $0,020<0,05 \quad\left(\mathrm{P}_{\text {hitung }}<\alpha\right)$ dan uji $\mathrm{t}$ juga menunjukan 2,337 $>1,967$ ( $\left.\mathrm{t}_{\text {hitung }}>\mathrm{t}_{\text {tabel }}\right)$. Hal ini menunjukan bahwa variabel kebiasaan belajar siswa berpengaruh terhadap hasil belajar siswa pada mata pelajaran ekonomi, artinya semakin tinggi kebiasaan belajar yang dimiliki oleh siswa maka hasil belajar siswa akan semakin efektif, begitupun sebaliknya jika kebiasaan belajar yang dimiliki oleh siswa menurun maka hasil belajar siswa akan menurun.

Kondisi tersebut sejalan dengan penelitian yang dilakukan Raiz, dkk,. (2002, hl. 36) bahwa adanya hubungan yang positif antara hasil belajar siswa dengan faktor-faktor kebiasaan belajar seperti jadwal studi, kebiasaan mencatat dan menulis. Diperkuat oleh temuan Sarwar, dkk., (2009, hlm.207) bahwa siswa dengan kebiasaan dan sikap belajar yang baik cenderung memiliki hasil akademik yang tinggi. Demikian pula penelitian lainnya yang dilakukan oleh Aisha, dkk., (2002), Fielden (2004), Sirohi (2004), Laxminarayan (2006), Mark dan Howard (2009) menyimpulkan bahwa kebiasaan belajar yang buruk merupakan penyebab uatama dari rendahnya hasil belajar siswa. Dengan kata lain jika seorang siswa menunjukkan kebiasaan belajar yang negatif (misalnya tidak memiliki konsentrasi, merasa bosan, lelah dan mengantuk saat proses pembelajaran, menghabiskan sedikit waktu untuk belajar dan tidak memetakan tujuan langsung yang ingin dicapai) ada kemungkinan bahwa siswa kurang memiliki dorongan untuk terlibat secara maksimal dalam pembelajaran yang produktif selama alokasi waktu sekolah.

Berdasarkan temuan dilapangan dan hasil pengujian satatistik pada substruktural model I, makan dapat disimpulkan bahawa keberhasilan dalam belajar membutuhkan kontrol individu untuk menciptakan konsistensi rutinitas belajar dalam memperoleh dan membimbing proses kognitif yang dipengaruhi oleh kepribadian individu dan lingkungannya. Kepribadian individu salah satunya berupa motivasi belajar siswa yang akan mendorong siswa untuk menghabiskan waktu lebih lama untuk belajar sehingga terbentuk kebiasaan belajar yang efektif dan akan meningkatkan hasil belajar yang ada. Hasil belajar akan maksimal jika adanya motivasi belajar sehingga akan menimbulkan perhatian khusus dengan kata lain kebiasaan belajar timbul akibat adanya motivasi belajar pada siswa.

Hasil belajar siswa merupakan konsekuensi dari proses pembelajaran yang melibatkan guru sebagai subjek dan siswa sebagai objek. Proses pembelajaran disekolah merupakan salah satu cara untuk membantu siswa dalam menyelesaikan masalah kehidupan sehari-hari sehingga proses pembelajaran yang efektif mengharuskan adanya peran yang seimbang dari guru maupun siswa. Peran guru adalah memberikan treatment paling tepat bagi anak didiknya dengan kata lain kompetensi guru sangat berpengaruh dalam proses pembelajaran sedangkan peran siswa adalah mengikuti proses pembelajaran dengan baik. Proses pembelajaran tidak akan berjalan sesuai 
harapan jika siswa tidak memiliki motivasi untuk belajar. Sehingga kompetensi yang dimiliki guru dan motivasi belajar dari siswa akan mendorong kebiasaan belajar pada siswa sehingga hasil belajar yang merupakan konsekuensi proses pembelajaran akan dapat dimaksimalkan.

\section{KESIMPULAN}

Berdasarkan temuan dan pembahasan pada penelitian yang telah dilakukan, maka dapat ditarik kesimpulan berkaitan siswa kelas XI IPS pada SMA Negeri di Kabupaten Sumedang sebagai berikut :

1) Kompetensi guru ekonomi pada SMA Negeri di Kabupaten Sumedang tergolong tinggi.

2) Motivasi belajar yang dimiliki siswa pada kategori tinggi.

3) Kebiasaan belajar yang dimiliki siswa pada kategori tinggi.

4) Hasil belajar yang dimiliki siswa berada pada kategori tinggi.

5) Kompetensi guru berpengaruh positif terhadap kebiasaan belajar siswa.

6) Motivasi belajar siswa berpengaruh positif terhadap kebiasaan belajar.

7) Kompetensi guru berpengaruh positif terhadap hasil belajar mata pelajaran ekonomi siswa.

8) Motivasi belajar siswa berpengaruh positif terhadap hasil belajar.

9) Kebiasaan belajar siswa berpengaruh positif terhadap hasil belajar.

\section{DAFTAR PUSTAKA}

Aisha R, Kiran A and Malik NH. (2002. Relationship of study habits with educational achievements. International Journal of Agriculture and Biology 4(3): 370-371.

Awang, M. Sinnadurai. (2010). A Study on the Development of Strategic Tools in Study Orientation Skills towards Achieving. Journal of Language Teaching and Research, Vol. 2, No. 1, pp. 60-67, Academic Excellence ISSN 1798-4769

Cassidy, Simon. (2004). "Learning styles: An overview of theories, models, and measures". Educational Psychology, 24, (4), 419-443.

Child, D. (1981). Psychology and the Teacher. London: Holt, Rinehart and Winston

Crede, M. Kuncel N.R. (2008). Study habit, skills, and attitudes: the third pillar supporting collegiate academic performance. Perspectives on Psychological Science, 3, 425-453.

Crow,Lester D.,Crow,Alice.(2007).Educational Psychology. Delhi: Surject Publications

Emamepur, S. Shams, H. (2004). Study of learning styles in students of university and their relationship with academic achievement and gender. Psychological-educational Researches quarterly of Tarbiyat moalem, 5: 1-24.

Fielden, K. (2004). Evaluating Critical Reflection for Post-graduate Students in Computing. Informing Science and Information Technology Education (Joint Conference 2005, Flagstaff, Arizona).

Gordon, Thomas. (2003). Teacher effectiveness training. First Revised Edition. New York: Three Rivers Press

Heck, Ronald H. (2007). Examining the relationship between teacher quality as an organizational property of schools and students' achievement and growth rates. Educational Administration Quarterly. Volume 43 (4): 399-432

Homayoni, A. Abdolahi, M. (2003). Investigating correlation between learning styles and cognitive styles and their roles in academic achievement of students. Journal ofPsychology, 2: 179-197.

Hoy, Wayne K. Dan Miskel, Cecil G (2001). Educational Administration Theory, Resarch, and Practice 6th ed., International Edition, Singapore: McGraw-Hill Co 
Koetzner, J. (2006). Student Learning Outcome Mendocino College Library Fresno City College.

Isangedighi, A Jerome. (1997). A Comparison of Study Habits Among the Under Achieving, the Achieving and Over Achieving Junior Secondary Students. West African Journal of Educational Research, 1, 114-119.

Jones, C.H.,Slate, J.R., dan Marini, I. (1996). Graduate students study skills as a function of academic achievement, sex, conceptions of intelligence and locus of control. New Directions for Education Reform, 3, 61-78

Keller, Jhon M. (2004). A predictive model of motivation, volition, and multimedia learning. In Proceedings of the International Symposium \& Conference, Educational Media in Schools (pp. 9-19): Osaka, Japan: Kansai University.

Mark A, Howard C (2009). How to Study. Psychol. Sci. 20(4):516-522.

Mendezabal MJN (2013). Study Habits and Attitudes: The Road to Academic Success. Open Science Repository Education. doi:10.7392/Education.70081928

Nizam (2016, 15 Desember). Daya Imajinasi Siswa Lemah. Kompas, hlm.11.

Nonis, A Sarath., Hudson, Gail I. (2010). Performance of College Students: Impact of Study Time and Study Habits. Journal of Education for Business, 85 (4): 229-238.

Nuthana, P.Gdan Yenagi, G.V.(2009): influence of study habits, self concept on achievement of boys and girls. Karnataka Journal of Agricultural Sciences Vol.22 No.51135-1138

Okpala, A. O., Okpala, C. O., dan Ellis, R. (2000). Academic effort and study habits among college students in principles of macroeconomics. Journal of Education for Business, 75, 219-224.

Oluwatimilehin, J.T.B., dan Owoyele, J.W. (2012). Study habits and academic achievement in core subjects among junior secondary school students in Ondo state, Nigeria. Bulgarian Journal of Science and Education Policy (BJSEP), 6(1), 155-169.

Ozsoy, Gokhan., Memis, Aysel., Temur, Turan. (2009). Metacognition, study habits and attitudes. International Electronic Journal of Elementary Education, 2(1), 154-166.

Pratt, Daniel. (1989). Three Stages of Teacher Competence: A Developmental Perspective. New Dirmionr lor Continuing Eduation. No. 43. SanFrank Joluy-b.Fall. Page 77-87.

Rahmawati (2016, 15 Desember). Daya Imajinasi Siswa Lemah. Kompas, hlm.11.

Raiz, A., Kiran, A., dan Malik, N.H. (2002). Relationship of Study Habits with Educational Achievements. International Journal of Agriculture dan Biology. 4(3), 370-37.

Rana S, Kausar R (2011). Comparison of Study Habits and Academic Performance of Pakistani British and White British Students. Pakistan J. Social and Clinical Psychol. 9: 21-26.

Razia, B. (2015). Study Habits Of Secondary School Students In Relation To Their SocioEconomic Status And Gender. International of Social Sciences and Management. Vol-2, issue-1: $68-73$

Sarwar M, Bashir M, Khan NM, Kahn SM (2009). Study-orientation of High and Low Academic achievers at Secondary level in Pakistan. Academicjournals., April. Educ. Res. Rev. 4(4):204-207.

Siahi, Evans A., dan Maiyo, Julius K. (2015). Study of the relationship between study habits and academic achievement of students: A case of Spicer Higher Secondary School, India. International Journal of Educational Administration and Policy Studies. 7(7), 134-141. 
Singh, Y G. (2011). Academic achievement and study habits of higher secondary students. International Referred Research Journal, 3(27): 19-20.

Sirohi V (2004) A study of under-achievement in relation to study habits and attitude. Journal of Indian Education 30(1): 14-19.

Stevenson, S. (2005). "What is Assessment? UAF Provost's Office".

Surachim, Ahim. (2013). Pengaruh Motivasi Belajar, Kompetensi Guru, Fasilitas Belajar dan Efektifitas Pembelajaran terhadap Kemampuan Kerja Lulusan SMK di Kota Bandung. Disertasi UPI

Sumber lainnya :

Data Ujian Nasional 2012-2016. Bandung : Dinas Pendidikan Jawa Barat.

https://timssandpirls.bc.edu/data-release-2011/pdf/Overview-TIMSS-and-PIRLS-2011Achievement.pdf

https://timssandpirls.bc.edu/data-release-2015/pdf/Overview-TIMSS-and-PIRLS-2015Achievement.pdf 